Arq. Bras. Med. Vet. Zootec., v.73, n.5, p.1180-1186, 2021

\title{
Triticale silage replaces sorghum silage in finishing of Braford heifers
}

[Silagem de triticale substitui silagem de sorgo na terminação de novilhas da raça Braford]

\author{
A.M. Oliveira ${ }^{1}$, L.D.F. Silva ${ }^{(\mathbb{D}}$, A.P.O. Souza1 ${ }^{1}$, E.L.A. Ribeiro ${ }^{2}$, \\ C.C. Jobim ${ }^{3}$, V.H. Bumbieris Júnior ${ }^{2}$ (D) \\ ${ }^{1}$ Graduate, Universidade Estadual de Londrina, Londrina, PR, Brasil \\ ${ }^{2}$ Universidade Estadual de Londrina, Londrina, PR, Brasil \\ ${ }^{3}$ Universidade Estadual de Maringá, Maringá, PR, Brasil
}

\begin{abstract}
The aim of this study was to evaluate the effect of sorghum silage substitution with different proportions of triticale silage on the performance and carcass of Braford heifers. Twenty-four Braford heifers were randomly assigned to four diets where sorghum silage was replaced at $0 \%, 30 \%, 60 \%$, and $100 \%$ for triticale silage in a feedlot system. During sixty-tree days of the experiment, the feed intake, feed ratio conversion, and average daily gain were measured. The heifers were slaughtered and the effects of the sorghum and triticale silage in carcass characteristics were evaluated. The replacement of sorghum silage with triticale silage did not affect the feed intake and average daily gain $(\mathrm{P}>0.05)$. Feed gain ratio was higher for the heifers that received lower proportions of triticale silage $(0 \%$ and $30 \%)$ in replace sorghum silage $(\mathrm{P}<0.05)$. Eye loin area and fat thickness were similar among treatments $(\mathrm{P}<0.05)$. Other carcass characteristics, such as slaughter live weight, dressing percentage, conformation and fat classification were similar among experimental treatments $(\mathrm{P}<0.005)$. Triticale silage can replace sorghum silage for finishing beef heifers in feedlot system and provides similar carcass characteristics.
\end{abstract}

Keywords: beef cattle, carcass, Sorghum bicolor, X. Triticosecale Wittmack, winter cereals

\section{RESUMO}

O objetivo deste trabalho foi avaliar o efeito da substituição da silagem de sorgo por diferentes proporções de silagem de triticale no desempenho e na carcaça de novilhas Braford. A silagem de sorgo foi substituída em 0\%, 30\%, 60\% e 100\% pela silagem de triticale como fonte de volumoso na alimentação de 24 novilhas da raça Braford, em um sistema de confinamento. O período experimental total foi de 63 dias para a avaliação do consumo dos componentes da ração, a conversão alimentar e o ganho médio diário. Ao final do experimento, os animais foram abatidos e avaliados em relação às características de carcaça. A substituição da silagem de sorgo pela silagem de triticale não apresentou efeito no consumo dos componentes da ração e no ganho médio diário entre as novilhas $(P>0,05)$. A conversão alimentar foi melhor para as novilhas que receberam menores proporções de silagem de triticale $(0 \%$ e $30 \%)$ em substituição à silagem de sorgo $(P<0,05)$. As características das carcaças foram semelhantes entre os animais independentemente da fonte de volumoso. A silagem de triticale apresentase como alimento alternativo à silagem de sorgo em regiões de transição climática para a terminação de novilhas de corte, proporcionando o mesmo desempenho animal e as mesmas características de carcaça.

Palavras-chaves: bovino de corte, carcaça, cereal de inverno, Sorghum bicolor, X. Triticosecale Wittmack

\section{INTRODUCTION}

Cereals are essential in animal feed. They provide grains and pastures and are used to form conservation feed. The silages of whole corn and sorghum are a source of preservation forage in the finishing of Brazilian beef cattle (Bernardes et al., 2018). However, in climatic transition regions, such as in the south, part of the southeast, and midwestern of Brazil, temperature variations can be significant and affect the production of tropical cereals and the quality of forage material (Horst et al., 2018).

Corresponding author: aline.marangon@ufv.br

Submitted: January 16, 2021. Accepted: May 24, 2021. 
In regions of climatic transition, winters are mild, allowing the growth and development of winter cereals. Paraná state is the greatest producer of winter cereals in Brazil; however, there are variations in the growing area, with reductions applied between harvests CONAB (Boletim..., 2020). In this context, the permanent growth areas are not used during the winter and can be used for growing crops for silage production, enabling the rational use of soils and providing high-quality nutritional forage for the development of livestock in the region (Bumbieris et al., 2011; Lehmen et al., 2014).

The winter silages have been studied mainly in relation to their agronomic, productive, and fermentative aspects (Meinerz et al., 2011; Mattos Leão et al., 2019). Studies have shown that winter cereals have high levels of crude protein, good production levels of dry matter, and provide high-quality fiber to animal feed (Jobim et al., 1996; Bumbieris et al., 2011; Henz et al., 2020). However, few studies have evaluated the effects of these cereal silages and their performance in finishing beef cattle, particularly related to triticale silage. Triticale is a notable cropping option due to its wide capacity for environmental adaptation, mainly in subtropical transition regions Emile et al. (2007). The aim of this study was to evaluate the hypothesis that sorghum silage can be replaced by triticale silage without altering intake feed, performance, or carcass characteristics in Braford heifers in a feedlot system.

\section{MATERIALS AND METHODS}

The experimental protocol (number 2184.2016.97) was designed to adapt the existing directives of the Ethics and Animal Use Committee (CEUA) of the State University of Londrina, Paraná, Brazil. The experiment was performed at the Farm School of the State University of Londrina, located in Londrina,

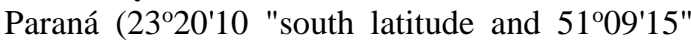
west longitude, with $610 \mathrm{~m}$ altitude).

Triticale (Triticosecale cv. BRS Harmonia) was grown in early June 2016. The cut occurred when the cultivar presented $45 \%$ DM, phenological stage dough seed, with an average yield of $13.330 \mathrm{~kg}$ of dry matter per hectare. Sorghum (Sorghum bicolor L., cv. Volumax) was grown in October 2016 and was cut with
$35 \%$ DM, phenological stage seed milky in January 2017.

Three bunker silos $\left(67.5 \mathrm{~m}^{3}\right)$ with a capacity of 33.8 tons (density $500 \mathrm{~kg} / \mathrm{m}^{3}$ ) were made for triticale silage. One bunker silo $\left(250 \mathrm{~m}^{3}\right)$ with a capacity of 125 tons (density $500 \mathrm{~kg} / \mathrm{m}^{3}$ ) was made for sorghum silage. Shortly after cutting, the forage mass was compacted and sealed with double-sided canvas. On the preparation of the triticale silage, an enzyme-bacterial inoculant (Lactosilo®, BASF, Brazil) was used, according to the manufacturer's recommendations, to provide the same ambient fermentation conditions as the sorghum silage. The opening of the silos occurred in June 2017, during an animal performance assessment.

After the opening of the silos, samples of the silages were taken weekly Compound samples were subjected to bromatological evaluations, $\mathrm{pH}$ evaluations, and ammoniacal nitrogen (N-NH3) over a period of 21 days. The $\mathrm{pH}$ was evaluated according to the methodology described by Kung et al. (1984), while $\mathrm{N}$-ammoniacal was evaluated by the steam distillation method according to Playne and McDonald (1966).

The bromatological analyses proceeded after the samples were pre-dried in a forced ventilation oven at $55 \pm 5^{\circ} \mathrm{C}$ for 72 hours and processed in a knife mill using a $1 \mathrm{~mm}$ sieve (Table 1). The values of dry matter (DM), nitrogen content (CP), mineral matter (MM), and ether extract (EE) were obtained following the methodology of Association of Official Analytical Chemists (Official..., 1990). The neutral detergent fiber (NDF) was analyzed using the methodology described by Mertens et al. (2002). Lignin was analyzed after the NDF, in an acidic detergent, by the method of acid hydrolysis (Van Soest et al., 1991).

The silage samples were evaluated by means of near-infrared spectroscopy (NIRS) in a commercial laboratory for their values of starch, neutral detergent insoluble protein (NDIP), acid detergent insoluble protein (ADIP), losses fermentation values and acids fermentation (Table 1). Nonfibrous carbohydrates (NFC) were calculated using the equation: $\mathrm{NFC}=100-$ $(\mathrm{MM}+\mathrm{EE}+\mathrm{CP}+(\mathrm{NDF}-\mathrm{NDIP}))$, correcting the NDF values according to Hall (2000). 
Oliveira et al.

Table 1. Chemical composition and fermentation profile of triticale and sorghum silages

\begin{tabular}{llllll}
\hline $\begin{array}{l}\text { Chemical composition } \\
(\% \mathrm{DM})\end{array}$ & $\mathrm{TS}$ & $\mathrm{SS}$ & Fermentation profile (\%DM) & $\mathrm{TS}$ & $\mathrm{SS}$ \\
\hline Dry matter (\%NM) & 39.19 & 30.17 & $\mathrm{pH}$ & 4.24 & 4.22 \\
Crude protein & 8.64 & 7.63 & Ammoniacal nitrogen(\%CP) & 5.82 & 6.69 \\
NDIP (\% CP) & 0.91 & 0.57 & Lactic acid & 2.77 & 2.52 \\
ADIP (\% CP) & 8.38 & 4.50 & Acetic Acid & 1.69 & 2.42 \\
Ethereal extract & 2.11 & 2.31 & Butyric acid & 0.00 & 0.15 \\
NDF & 58.22 & 46.10 & Fermentative losses & 2.84 & 4.66 \\
Lignin & 4.38 & 2.60 & & & \\
Starch & 12.10 & 25.22 & & & \\
Mineral matter & 5.83 & 5.95 & & & \\
NFC & 26.11 & 39.58 & & & \\
\hline
\end{tabular}

TS: triticale silage; SS: sorghum silage; NDIP: neutral detergent insoluble protein; ADIP: acid detergent insoluble protein; detergent; NDF: neutral detergent fiber; NFC: non-fibrous carbohydrates;

Animal performance was evaluated using twenty-fourBraford heifers, with an average initial weight of $346 \pm 11.7 \mathrm{~kg}$, previously dewormed, and vaccinated. The heifers stayed in feedlot system with open access to water and food, distributed in collective pens, with three animals each. Thirty days before performance evaluation, the heifers were adapted to the nutritional, environmental, and management conditions.

The diets consisted of replacing the sorghum silage to triticale silage in different proportions, in $0 \%=100 \%$ sorghum silage; $30 \%=30 \%$ triticale silage $+70 \%$ sorghum silage; $60 \%=$
$60 \%$ triticale silage $+40 \%$ sorghum silage; and $100 \%=100 \%$ triticale silage.

The experimental diets were formulated to satisfy the nutritional requirements and weight gain estimated at $1000 \mathrm{~g} \mathrm{day}^{-1}$ according to the Nutrient Requirements of Beef Cattle, (2015) (Table 2). The concentrated portion of the diets was formulated from corn and soybean meal combined with a vitamin-mineral mixture. The roughage:concentrate ratio was 40:60. The animals were fed twice a day ( 8 am and $5 \mathrm{pm})$ in the form of total mixed feed (RTM) with control of leftovers approximately $20 \%$.

Table 2. Calculated chemical composition of diets with different levels of triticale silage to replace sorghum silage

\begin{tabular}{lcccc}
\hline Variables (\% DM) & \multicolumn{4}{c}{ Levels of triticale silage (\%) } \\
\cline { 2 - 5 } & 0 & 30 & 60 & 100 \\
\hline Dry matter (\% NM) & 50.31 & 52.74 & 55.42 & 59.44 \\
Crude Protein & 12.76 & 12.63 & 13.71 & 13.64 \\
Ethereal Extract & 3.19 & 3.70 & 2.93 & 2.98 \\
Neutral Detergent Fiber & 29.39 & 30.82 & 31.95 & 34.26 \\
Lignin & 1.04 & 1.25 & 1.47 & 1.75 \\
Organic matter & 86.43 & 86.28 & 86.22 & 86.21 \\
Total Digestible Nutrients & 67.22 & 66.31 & 64.48 & 62.46 \\
Metabolizable energy (Mcal/kg DM) & 2.53 & 2.45 & 2.45 & 2.36 \\
\hline
\end{tabular}

NM: natural matter

Samples of food and remains were collected once a week and weighed after all meals. The sample remains were gathered over a period of 21 days and frozen for subsequent analysis at the Animal Nutrition Laboratory of the State University of Londrina (LANA - UEL). During the same 21-day period, the animals were weighed on a digital scale after fasting from solids for a period of 12 hours.

The food and remains samples were processed and analyzed in a similar way to the triticale and sorghum silages for the determination of $\mathrm{CP}$, MM, EE, NDF, and lignin. For the remains and 
concentrated food samples, alpha-amylase was added to the NDF analysis. According to the results of the animal weight were calculated: the weight of the feed supplied, the weight of the leftovers and bromatological analyses, the consumption of nutritive compounds, feed: ratio (FR), and average daily gain (ADG).

After the 63-day experimental period, the animals were slaughtered. Before slaughter, the animals were subjected to fasting from solids and liquids for 16 hours and weighed before boarding (SLW). The slaughter was carried out in a commercial slaughterhouse according to the recommendations of the MAPA Brasil (2017) with stunning by the percussive method using a pneumatic pistol. The carcasses were weighed before cooling to obtain the hot carcass weight (HCW). The dressing percentage (DP) was obtained by the ratio of the $\mathrm{HCW}$ value to the SLW and multiplied by 100 . The carcasses were classified according to the degree of conformation (values from 1 - concave to 6 convex) and fat classification (values from 1 cover fat absent to 5 - excess cover fat) by means of photographic standards, according to Cañeque and Sañudo (2005). In the section of the 12th rib, the fat thickness was read using a caliper and the eye loin area was measured.

The data were submitted to the Shapiro-Wilk and Bartlett tests in order to verify the normality and homogeneity of the variance. The performance variables were subjected to analysis of variance for a completely randomized experimental design in plots subdivided over time, analyzing the four treatments, with two repetitions per treatment totaling six animals per treatment, in the three evaluation periods. The carcass data were subjected to analysis of variance for a completely randomized design, considering four treatments with six replicates per treatment. The $5 \%$ confidence probability was accepted on the F test, and then the Tukey test of multiple comparisons at 5\% significance was used in the statistical program $\mathrm{R}$.

\section{RESULTS}

Although, sorghum and triticale silages showed bromatological differences and suitable fermentation conditions (Table 1), the feed intake did not differ $(\mathrm{P}>0.05)$ among the heifers (Table 3).

Table 3. Daily voluntary dry matter (DM) intake (Means \pm SEM) and dietary components for Braford heifers fed diets containing different levels of triticale silage to replace silage sorghum

\begin{tabular}{lcccccccc}
\hline Intake & \multicolumn{3}{c}{ Levels of triticale silage $(\%)$} & & \multicolumn{3}{c}{ Periods } \\
\cline { 2 - 4 } \cline { 6 - 8 } (kg) & 0 & 30 & 60 & 100 & & P1 & P2 & P3 \\
\hline DM & $10.30 \pm 0,35$ & $10.25 \pm 0,34$ & $10.47 \pm 0,36$ & $9.89 \pm 0,35$ & & $8.59 \pm 0,37 \mathrm{c}$ & $11.65 \pm 0,36 \mathrm{a}$ & $10.44 \pm 0,38 \mathrm{~b}$ \\
CP & $1.60 \pm 0,054$ & $1.61 \pm 0,052$ & $1.66 \pm 0,054$ & $1.60 \pm 0,052$ & & $1.38 \pm 0,056 \mathrm{c}$ & $1.82 \pm 0,056 \mathrm{a}$ & $1.66 \pm 0,056 \mathrm{~b}$ \\
EE & $0.40 \pm 0,012$ & $0.39 \pm 0,011$ & $0.40 \pm 0,012$ & $0.37 \pm 0,011$ & & $0.33 \pm 0,011 \mathrm{c}$ & $0.44 \pm 0,011 \mathrm{a}$ & $0.39 \pm 0,011 \mathrm{~b}$ \\
NDF & $3.46 \pm 0,016$ & $3.32 \pm 0,015$ & $3.42 \pm 0,016$ & $3.17 \pm 0,015$ & & $2.74 \pm 0,017 \mathrm{c}$ & $3.84 \pm 0,018 \mathrm{a}$ & $3.44 \pm 0,017 \mathrm{~b}$ \\
Lignin & $0.10 \pm 0,009$ & $0.11 \pm 0,009$ & $0.13 \pm 0,009$ & $0.15 \pm 0,009$ & & $0.09 \pm 0,009 \mathrm{~b}$ & $0.15 \pm 0,009 \mathrm{a}$ & $0.13 \pm 0,01 \mathrm{a}$ \\
MM & $0.46 \pm 0,016$ & $0.47 \pm 0,015$ & $0.48 \pm 0,016$ & $0.46 \pm 0,015$ & & $0.39 \pm 0,017 \mathrm{c}$ & $0.54 \pm 0,016 \mathrm{a}$ & $0.48 \pm 0,017 \mathrm{~b}$ \\
\hline
\end{tabular}

Means followed by distinct lower-case letters between the columns indicate difference according to the Tukey test (0.05). CP: crude protein; EE: ethereal extract; NDF: neutral detergent fiber; MM: mineral matter; SEM: standard error of mean.

Thus, there was no influence $(\mathrm{P}>0.05)$ on the dry matter intake (means \pm standard error of mean $(\mathrm{SEM})=10.23 \pm 0.29)$, crude protein intake $(1.62 \pm 0.04)$, ether extract intake $(0.39 \pm 0.01 \mathrm{~kg})$, $\mathrm{NDF}$ intake $(3.35 \pm 0.07 \mathrm{~kg})$, lignin intake $(0.12 \pm 0.01 \mathrm{~kg})$ and mineral matter intake $(0.47 \pm 0.01 \mathrm{~kg})$.

The feed ratio was different $(\mathrm{P}<0.05)$ between the levels when replacing sorghum silage with triticale silage (Table 4). Heifers fed $0 \%$ and $30 \%$ triticale silage had better feed conversion (7.32 and $7.53 \mathrm{~kg}$, respectively) than animals fed 60 and $100 \%$ triticale silage $(8.41$ and $8.59 \mathrm{~kg}$, respectively). However, there was no difference $(\mathrm{P}>0.05)$ in average daily weight gain $(1.33 \pm 0.16 \mathrm{~kg})$ and slaughter live weight (435.95 \pm 0.85$)$.

Carcass characteristics were not influenced $(\mathrm{P}>$ $0.05)$ by different levels of triticale silage in replacement of sorghum silage (Table 4). Thus, the dressing percentage $(55.64 \pm 0.36 \%)$, conformation classification $(3.33 \pm 0.13)$, fat classification (3.00 \pm 0.13$)$, eye loin area $(62.04 \pm 1.88 \mathrm{~cm} 2)$ and, fat thickness $(8.13 \pm 0.09 \mathrm{~mm})$. 
Oliveira et al.

Table 4. Performance and carcass characteristics of Braford heifers fed diets containing different levels of triticale silage to replace silage sorghum

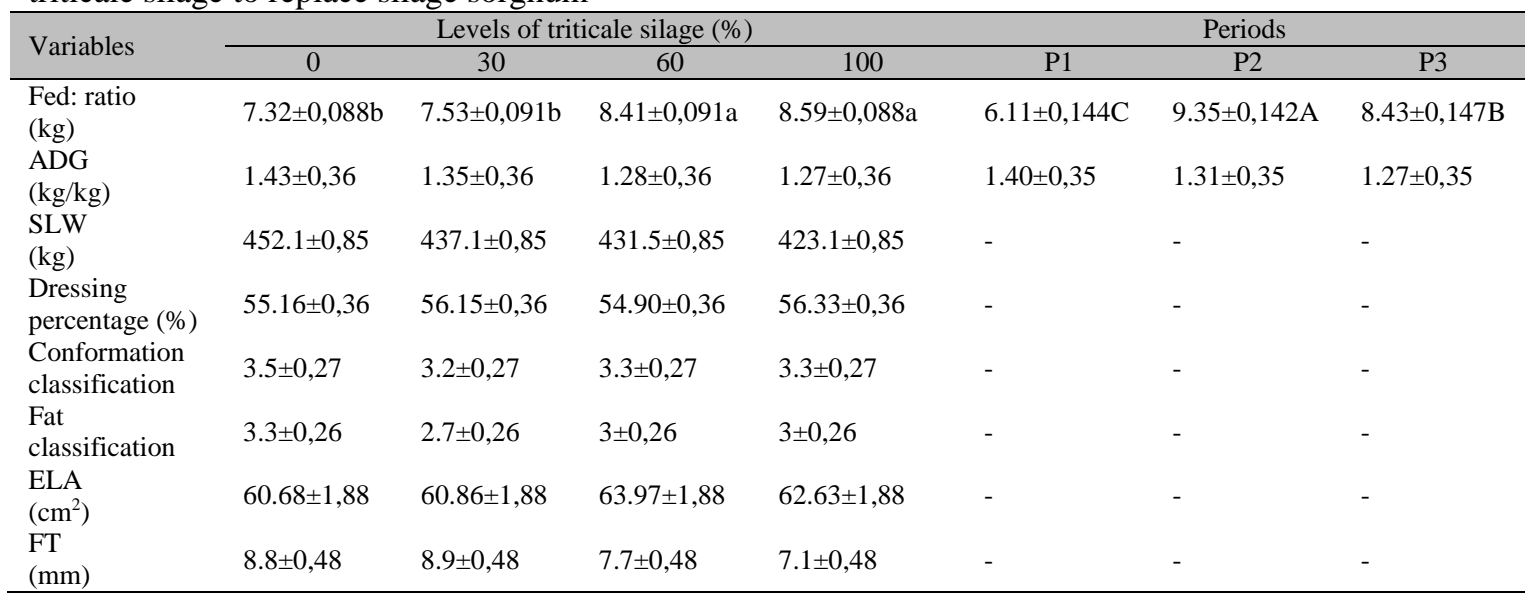

Conformation based on the Cañeque and Sañudo, (2005) classification system where $\mathrm{E}=1$ and $\mathrm{P}=5$. Fat classification based on a 5point scale where 1 - cover fat absent to 5 - excess cover fat. Means followed by different lower-case letters between the columns indicate difference according to the Tukey test (0.05). ADG: average daily gain; SLW: Slaughter live weight; ELA: Eye Loin Area; FT: fat thickness. SEM = standard error of mean.

\section{DISCUSSION}

The intake of forage conserved by ruminants can be influenced by the chemical composition and quality of the fermentation. The sorghum silage had a higher NFC content $($ SS $39.58 \times$ ST $26.11 \%$ DM) compared to triticale silage, but this condition was not sufficient to show differences in the fermentative quality of the silages or any interference with the feed intake (Table 1 and 3). Both silages had appropriated fermentative characteristics used for forage crops with a final $\mathrm{pH}(\mathrm{ST} 4.24 \times \mathrm{SS} 4.22)$, ammoniacal nitrogen (ST $5.82 \times$ SS $6.69 \% \mathrm{~PB})$, acetic acid (ST 1, $69 \times$ SS $2.42 \%$ DM), butyric acid (ST $0.00 \times \mathrm{SS} 0.15 \% \mathrm{MS})$ and lactic acid (ST $2.77 \times$ SS $2.52 \%$ MS) according to Kung et al. (2018). The fermentation conditions, after the establishment of the anaerobic condition, involved a population of lactic acid bacteria (LAB) predominating in the ensiled mass, starting the fermentation process through the transformation of available carbohydrates into lactic acid, decreasing the $\mathrm{pH}$ and the populations of enterobacteria, fungi, and yeasts. The process occurred until the stabilization phase when the $\mathrm{pH}$ reached half the growth of LAB (Pahlow et al., 2015; Kung et al., 2018). The compounds formed during the silage fermentation process are used in ruminal metabolism for the formation of volatile fatty acids (VFA), providing a suitable amount and energy conditions for animal performance (Grant and Ferraretto 2018; Kung et al. (2018).

Heifers that consumed lower levels of triticale silage to replace sorghum silage showed better conversion compared to heifers that received above $60 \%$ triticale silage to replacing sorghum silage (Table 3). Regarding the average daily gain (ADG), the slaughter weight (SW) and the carcass yield (CY) all the Braford heifers had similar results, regardless of the source of forage.

The best conversion by heifers that received lower levels of triticale silage can be attributed to the bromatological differences of the silages (Table 1). Triticale silage provided a higher protein content compared to sorghum silage; however, it also presented a higher lignin and NDF content and lower NFC and starch values. Henz et al. (2020), using a degradability test, demonstrated that triticale silage provides a greater amount of high availability and potentially degradable protein in the rumen compared to sorghum silage. Thus, the authors suggest that, from a nutritional view, the use of triticale silage would be interesting when added to diets with a high content of fast fermenting carbohydrates, providing adequate ruminal fermentation and improving animal performance.

The use of starch content in the feeding of ruminants currently highlights not only the use of starch by ruminal bacteria and the formation of 
VFA but also the intestinal digestion of this component and glucose absorption Reynolds et al. (2014). The absorption of intestinal glucose after digestion of starch increases the energy supply for animal metabolism, in addition to the VFA produced in the rumen Lohrenz et al. (2011) and Mills et al. (2017). Thus, due to the higher starch content observed in sorghum silage (Table 1), it is assumed that under certain experimental conditions, $100 \%$ and $70 \%$ sorghum silage as a source of roughage provides a greater supply of starch to the rumen and intestine, improving the feed conversion of the animals. However, it is worth mentioning that in previous studies, Lopes et al. (2008) and Jobim et al. (1996) demonstrated that the nutritional variability depends on the vegetative state in which the triticale will be harvested. Therefore, it is suggested that triticale silage, when harvested at later stages, may provide a greater supply of starch due to the inclusion of grains in the mass ensiled.

The heifers developed the same degree of muscularity (ELA and conformation), finishing, fat thickness, and carcass yield (Table 4). Triticale and sorghum silages have different bromatological characteristics (Table 1); however, they provided similar conditions of energy and protein for the growth of fat and muscle tissue. Thus, triticale silage can be used as an alternative food to increase the availability of roughage in rural properties, especially those in the climate transition regions. In addition, triticale silage poses as a strategic cereal in forage planning, harmless to animal performance, and can be harvested according to the interests of the farmer.

\section{CONCLUSIONS}

Triticale silage can replace sorghum silage in the finishing of Braford heifers when including $40 \%$ roughage in diets. It enables the same animal performance and carcass characteristics. Triticale silage as a strategic forage can be a supplemental high-quality forage for properties located in climatic transition regions.

\section{ACKNOWLEDGMENT}

To the National Council for Scientific and Technological Development (CNPq) for financing the project. To the Coordination for the
Improvement of Higher Education Personnel (CAPES) for the granting of a master's scholarship for the first author.

\section{REFERENCES}

BERNARDES, T.F.; DANIEL, J.L.P.; ADESOGAN, A.T. et al. Silage review: unique challenges of silages made in hot and cold regions. J. Dairy Sci., v.101, p.4001-4019, 2018.

BOLETIM safra grãos. Brasilia: CONAB, 2020. Disponível em: https://www.conab.gov.br/infoagro/safras/graos/boletim-da-safra-de-graos.

Acessado em: 21 abr. 2020.

BRASIL. Ministério de Agricultura, Pecuária e Abastecimento. Regulamento de inspeção industrial e sanitária de produtos de origem animal. 2017.

BUMBIERIS, V.H.; JOBIM, C.C.; EMILE, J.C. et al. Degradabilidade ruminal e fracionamento de carboidratos e proteínas em silagens de triticale em cultivo singular ou em misturas com aveia e/ou leguminosas. Semin. Agrar., v.32, p.759-770, 2011.

CAÑEQUE, V.; SAÑUDO, C. Estandarización de las metodologías para evaluar la calidad del producto (animal vivo, canal, carne y grasa) en los rumiantes. Madrid: INIA, 2005.

EMILE, J.C.; JOBIM, C.C.; SURAULT, F. et al. Genetic variations in the digestibility in sheep of selected whole-crop cereals used as silages. Animal, v.1, p.1122-1125, 2007.

GRANT, R.J.; FERRARETTO, L.F. Silage review: Silage feeding management: Silage characteristics and dairy cow feeding behavior. $J$. Dairy Sci., v.101, p.4111- 4121, 2018.

HALL, M. Neutral detergent-soluble carbohydrates nutritional relevance and analysis: a laboratory manual. Gainesville: University of Florida. 2000. [77p.].

HENZ, É.L.; SILVA, L.D.D.F.; BUMBIERIS JUNIOR, V.H. et al. Evaluation and characterization of triticale silage (x. Triticosecale wittmack) to replace Sorghum bicolor (L.) Moench (S. Vulgare Pers.) silage as feed for beef cattle. Semin. Agrar., v.41, p.335343, 2020. 
HORST, E.H.; NEUMANN, M.; MAREZE, J. et al. Nutritional composition of pre-dried silage of different winter cereals. Acta Sci. Anim. Sci., v.40, p.42500, 2018.

JOBIM, C.C.; REIS, R.A.; ROSA, B. et al. Avaliação do triticale (X triticosecale wittimack) para silagem. Rev. Bras. Zootec., v.25, p.404413, 1996.

KUNG, L.; GRIEVE, D.B.; THOMAS, J.W. et al. Added ammonia or microbial inocula for fermentation and nitrogenous compounds of alfalfa ensiled at various percents of dry matter. J. Dairy Sci., v.67,, p.299-306, 1984.

KUNG, L.; SHAVER, R.D.; GRANT, R. J. et al. Silage review: Interpretation of chemical, microbial, and organoleptic components of silages. J. Dairy Sci., v.101, p.4020-4033, 2018.

LEHMEN, R.I.; FONTANELI, R.S.; FONTANELI, R.S. et al. Rendimento, valor nutritivo e características fermentativas de silagens de cereais de inverno. Cienc. Rural, v.44, p.1180-1185, 2014.

LOHRENZ, A.K.; DUSKE, K.; SCHÖNHUSEN, U. et al. Glucose transporters and enzymes related to glucose synthesis in small intestinal mucosa of mid-lactation dairy cows fed 2 levels of starch. J. Dairy Sci., v.94, p.4546-4555, 2011.

LOPES, F.C.F.; OLIVEIRA, J.S.; LANES, E.C.M. et al. Valor nutricional do triticale (X Triticosecale Wittimack) para uso como silagem na Zona da Mata de Minas Gerais. Arq. Bras. Med. Vet. Zootec., v.60, p.1484-1492, 2008.

MATTOS LEÃO, G.F.; JOBIM, C.C.; NEUMANN, M. et al. Aspectos produtivos e nutricionais de cereais de inverno em regimes de corte para ensilagem. Arch. Zootec., v.68, p.128136, 2019.
MEINERZ, G.R.; OLIVO, C.J.; FONTANELI, R.S. et al. Valor nutritivo da forragem de genótipos de cereais de inverno de duplo propósito. Rev. Bras. Zootec., v.40, p.1173-1180, 2011.

MERTENS, D.R.; ALLEN, M.; CARMANY, J. et al. Gravimetric determination of amylasetreated neutral detergent fiber in feeds with refluxing in beakers or crucibles: collaborative study. J. AOAC Int., v.85, p.1217-1240, 2002.

MILLS, J.A.N.; FRANCE, J.; ELLIS, J.L. et al. A mechanistic model of small intestinal starch digestion and glucose uptake in the cow. J. Dairy Sci., v.100, p.4650-4670, 2017.

NUTRIENT requirements of beef cattle. 8.ed. revised. Washington: National Academies Press, 2015.

OFFICIAL methods of analysis of the Association of Official Analytical Chemists. 15.ed. Washington: AOAC, 1990.

PAHLOW, G.; MUCK, R.E.; DRIEHUIS, F. et al. Microbiology of ensiling. Silage Sci. Tech., v.42, p.31-93, 2015.

PLAYNE, M.J.; MCDONALD, P. The buffering constituents of herbage and of silage. J. Sci. Food Agric., v.17, p.264-268, 1966.

REYNOLDS, C.K.; HUMPHRIES, D.J.; VAN VUUREN, A.M. et al. Considerations for feeding starch to high-yielding dairy cows. J. Recent Adv. Anim. Nutr., p.9-11, 2014.

VAN SOEST, P.J.; ROBERTSON, J.B.; LEWIS, B.A. Methods for dietary fiber, neutral detergent fiber, and nonstarch polysaccharides in relation to animal nutrition. J. Dairy Sci., v.74, p.35833597, 1991. 